\title{
Contributing to food security in urban areas: differences between urban agriculture and peri-urban agriculture in the Global North
}

\author{
Ina Opitz ${ }^{1} \cdot$ Regine Berges $^{1,2} \cdot$ Annette Piorr ${ }^{1,2} \cdot$ Thomas Krikser $^{3}$
}

Accepted: 2 April 2015/Published online: 28 May 2015

(C) The Author(s) 2015. This article is published with open access at Springerlink.com

\begin{abstract}
Food security is becoming an increasingly relevant topic in the Global North, especially in urban areas. Because such areas do not always have good access to nutritionally adequate food, the question of how to supply them is an urgent priority in order to maintain a healthy population. Urban and peri-urban agriculture, as sources of local fresh food, could play an important role. Whereas some scholars do not differentiate between peri-urban and urban agriculture, seeing them as a single entity, our hypothesis is that they are distinct, and that this has important consequences for food security and other issues. This has knock-on effects for food system planning and has not yet been appropriately analysed. The objectives of this study are to provide a systematic understanding of urban and peri-urban agriculture in the Global North, showing their similarities and differences, and to analyse their impact on urban food security. To this end, an extensive literature review was conducted, resulting in the identification and
\end{abstract}

Regine Berges

berges@zalf.de

Ina Opitz

inaopitz@gmx.de

Annette Piorr

apiorr@zalf.de

Thomas Krikser

t.krikser@uni-kassel.de

1 Leibniz Centre for Agricultural Landscape Research (ZALF), Eberswalder Straße 84, 15374 Müncheberg, Germany

2 Agrathaer GmbH, Strategic Land Use, Eberswalder Str. 84, 15374 Müncheberg, Germany

3 Department of Agricultural and Food Marketing, Faculty of Organic Agricultural Sciences, University of Kassel, Steinstr. 19, 37213 Witzenhausen, Germany comparison of their spatial, ecological and socio-economic characteristics. The findings are discussed in terms of their impact on food security in relation to the four levels of the food system: food production, processing, distribution and consumption. The results show that urban and peri-urban agriculture in the Global North indeed differ in most of their characteristics and consequently also in their ability to meet the food needs of urban inhabitants. While urban agriculture still meets food needs mainly at the household level, peri-urban agriculture can provide larger quantities and has broader distribution pathways, giving it a separate status in terms of food security. Nevertheless, both possess (unused) potential, making them valuable for urban food planning, and both face similar threats regarding urbanisation pressures, necessitating adequate planning measures.

Keywords Urban food system · Urban gardening · Urban fringe $\cdot$ Metropolitan agriculture $\cdot$ Adaptation strategies

$\begin{array}{ll}\text { Abbreviations } \\ \text { CSA } & \begin{array}{l}\text { Community Supported Agriculture } \\ \text { European Union } \\ \text { EU }\end{array} \\ \text { FAO } & \begin{array}{l}\text { Food and Agriculture Organization of the } \\ \text { United Nations }\end{array} \\ \text { FFH } & \begin{array}{l}\text { Fauna Flora Habitat } \\ \text { International Federation of Organic } \\ \text { Agriculture Movements } \\ \text { Cooperative Library Network of Berlin- }\end{array} \\ \text { KOBV } & \begin{array}{l}\text { Brandenburg } \\ \text { Links between actions for the development } \\ \text { of the rural economy } \\ \text { LEADER-Governmental Organisation } \\ \text { NGO }\end{array} \\ \text { NYC } & \begin{array}{l}\text { New York City } \\ \text { Peri-urban agriculture }\end{array}\end{array}$


PURPLE Peri-urban Regions Platform Europe

UA

UPA

USA

SPIN
Urban agriculture

Urban and peri-urban agriculture

United States of America

Small-plot intensive

\section{Introduction}

Food security has become an increasingly relevant issue facing the Global North over the past few decades. The term 'food security' is defined as the state where all the members of a community have access to "culturally acceptable, nutritionally adequate food through local, nonemergency sources at all times" (Brown and Carter 2003, p. 4). In the US, at least $12 \%$ of households are affected by limited food supply at some point during a year (Macias 2008). The number of affected people increased from 33 million in 2001 (Brown and Carter 2003) to 45 million in 2010 (Besthorn 2013). Similar trends are noticeable in Europe regarding people dependant on soup kitchens or other emergency food sources. The report on the humanitarian impacts of the recent economic crisis in Europe indicated that on average in 22 European countries, the number of people dependant on food aid increased by $75 \%$ between 2009 and 2012 (International Federation of Red Cross and Red Crescent Societies 2013).

Besthorn (2013) states that food insecurity is an urban issue, in that by 2050, $67 \%$ of the world's population will live in urban areas (United Nations 2012). Accessibility, affordability and availability of food are the three core aspects of food security (Lang and Barling 2012) that cannot be completely ensured in urban areas. The existence of fewer grocery stores and more fast food restaurants has been documented in low-income neighbourhoods within cities in the US and Canada (Besthorn 2013), a phenomenon called 'food desert' (Segal 2010). As a result, accessibility and availability of nutritionally adequate food, especially fresh fruit and vegetables, is limited in those areas.

Acknowledging the large body of literature providing evidence that food demand will increase in importance for urbanised areas in the Global North, this paper seeks to review the state of knowledge and discussion on the supply side, particularly the roles of urban and peri-urban agriculture (PUA). Our hypothesis is that the two forms are distinct in ways that are important for food security and other issues.

\section{Urban agriculture and peri-urban agriculture in recent literature}

Historically, urban agriculture (UA) returned to cities in the Global North at a larger scale only in times of crisis, such

as in the form of "victory gardens" during the world wars, or as a reaction of the environmental movement (Mok et al. 2014). In the recent years, however, UA has become an increasingly relevant topic in the science and planning of urban food systems aimed at reducing food insecurity at the level of the household (Kortright and Wakefield 2011; Smith et al. 2013) and community (Howe 2002; Kremer and DeLiberty 2011; Besthorn 2013). While the contribution of UA to a resilient local food system is highly valued, the subject of UA itself remains vague. In recent years, scholars have developed various definitions of UA (Smit and Nasr 1992; Mougeot 2001; De Zeeuw et al. 2001; Dubbeling and Merzthal 2006; Mendes et al. 2008; Bohn and Viljoen 2010; Pearson et al. 2010; Ackerman 2011; van der Schans and Wiskerke 2012). The core concept at the heart of all these definitions is the understanding that UA involves food production in urban areas. This overarching description incorporates the general term 'agriculture', defining the various forms of farming and gardening most commonly undertaken in rural areas. Whether or not to include PUA as a facet of UA has been examined in several ways. While some scholars have focused on gardens and farms in inner city areas (Howe 2002; Broadway 2009; Cohen et al. 2012), others have included agricultural activities in the peri-urban areas in their research (Mougeot 2001; Pearson et al. 2010; van der Schans and Wiskerke 2012; Mok et al. 2014).

Peri-urban agriculture is a residual form of agriculture at the fringes of growing cities, though a commonly agreed spatial definition for peri-urban areas is missing. They are described as the transition zone between urban and rural areas with, on the one hand, lower population densities and a lack of infrastructure compared to cities, and therefore not "urban", and on the other hand a limited amount of agricultural and natural land, and therefore not "rural" (Allen 2003; Piorr et al. 2011). They suffer from urban pressures, but they also benefit from proximity to urban areas, markets and cultures, and are accordingly signified by a socio-cultural shift from rural to urban lifestyles (Antrop 2000; Piorr et al. 2011). Peri-urban agriculture takes place in this transition zone. Often located on fertile soils (Bryant and Johnston 1992) which historically provided urban centres with the majority of their perishable crops, peri-urban agriculture nowadays provides goods and services for the local up to the global market. It is sometimes referred to as "metropolitan agriculture" (Heimlich 1989) or "urban fringe agriculture" (Bryant 1997).

Debates on the distinction between urban and peri-urban areas apply such thresholds as population density or settlement pattern (Piorr et al. 2011). In order to distinguish UA from PUA, however, the geographical position of the fields alone (whether they are located within or beyond geographical borders of cities) seems to be inadequate. 
Aspects such as the level of professionalism, the achieved yields and the level of inclusion of the farmers in society and value chains all influence the assessment of an area's contribution to urban food security. A full analysis and comparison of relevant aspects of UA and PUA is still missing in the recent literature.

\section{Focussing on the Global North}

Comparing UA and PUA in the Global North and Global South reveals both similarities and differences. Certainly, the discussion of food security in urban areas differs. While food insecurity re-emerged in the cities of the Global North, and with it UA, it never went away in the Global South (Bryld 2003). The rapid, often uncontrolled growth, of some cities there led to an increase in poverty, food insecurity and unemployment in both the urban and periurban populations (FAO 2007; Dubbeling et al. 2010). UA and PUA are often not a choice; they are a means of survival, providing people not only with food, but also a living (Smit and Nasr 1992; Hamilton et al. 2014). Moreover, the lack of technologies such as a distribution cold chain or refrigerators at home reinforces the necessity to produce perishables close to urban centres. UA and PUA are discussed and promoted as strategies for sustainable development (Smit and Nasr 1992; FAO 2007; De Bon et al. 2010) and often regarded as one entity, regularly labelled UPA, the abbreviation for 'urban and peri-urban agriculture' (FAO 2007; De Zeeuw et al. 2011). Production in UA as well as in PUA in the Global South is characterised by the following features: It is both subsistence and market oriented, farmers and gardeners do not necessarily have a farming background (Dubbeling et al. 2010), production often takes place in polluted environments (De Bon et al. 2010), health risks prevail due to poor management and environmental pollution (Bryld 2003; Hamilton et al. 2014), it often lacks a legal status (Bryld 2003), and leisure or recreational activities are rarely to be found (Cabannes 2006). Consequently, to focus on the hypothesis of this paper, we do not examine the Global South and instead concentrate on UA and PUA in the Global North.

\section{Objectives}

The first objective of this study is to provide a systematic understanding of UA and PUA in the Global North by examining similarities and differences. The second objective is to use these results to analyse the impact of the respective agricultural system on food security in urban areas.

After introducing the material used, methods and definitions, and especially the various forms of agriculture, the results section outlines the comparison between UA and PUA along three dimensions: spatial, ecological and socio-economic. This ensures that the analysis of the two systems is systematic. Within each dimension, several factors are identified and described for UA and PUA. This opens an understanding of UA and PUA beyond the spatial categories of urban and peri-urban. All these aspects are relevant for the discussion of the impact of UA and PUA on food security at the different levels of a food system.

Facing the issue of urban food security, such knowledge can support future steering and management mechanisms with high transparency in decision processes, since it creates awareness of the suitability of UA and PUA for multiple objectives and highlights potential areas of conflict.

\section{Material, methods, and definitions}

\section{UA and PUA forms}

In this study, we analyse literature referring to the terms 'urban agriculture' and 'peri-urban agriculture' as well as literature on agricultural holdings and the most common forms of UA, including community gardens, allotments, backyard gardens, rooftop gardens and urban farms in the Global North.

Community gardens are self-organised initiatives or neighbourhood groups producing food or flowers for the personal or common benefit of their members (Ferris et al. 2001; Beilin and Hunter 2011; Rosol 2011). The members participate in the decision processes and share resources such as space, water and tools. Still, they can take up various different forms, especially regarding funding, ownership or aims (Guitart et al. 2012). Even though not every study on community gardens mentions food production, and therefore production cannot be assumed to occur in community gardens generally, we nevertheless get an improved understanding of UA by examining literature in this area.

Allotments are legally fixed forms of urban gardens. This definition particularly applies in Europe. Compared to community gardens, allotments are tended individually by plot holders and their families (Gröning 1996; van den Berg et al. 2010; Bendt et al. 2013). They are in most cases formally organised as associations with hierarchical structures, and are legally fixed in zoning plans.

Backyard gardens are predominantly private gardens and, just like balcony or terrace gardening, are associated with residential food production (Blake and Cloutier-Fisher 2009; Kortright and Wakefield 2011). Backyard gardens have shifted into the scope of UA, especially in North America where backyard sharing programs are converting private gardens into forms of community gardens (Blake and Cloutier-Fisher 2009; Lovell 2010). 
Rooftop farms and gardens can be organised collectively or privately. The defining aspect is their location on roofs, typically in urban areas. Consequently they belong to zero acreage farming (Specht et al. 2014).

Urban farms or city farms are located within the densely settled area (or the urban fringe) of a city. Operated by innovative entrepreneurs or charity organisations, the farms provide social or environmental services such as training (Mbiba 2003; Iles 2005), school gardening or day care (Dekking et al. 2007) in addition to food production.

Agricultural holdings are agrarian enterprises (single entrepreneurs or family businesses) that produce agrarian products on land the farmers own or rent, predominantly in peri-urban or rural areas. Agriculture is the primary or secondary occupation. As an official agricultural holding, owners are entitled to receive agricultural subsidies.

\section{Included literature}

The literature for this review was collected in a literature search and includes articles published up to November 2014. We conducted a double search process. In the first phase, the Web of Science, Scopus and KOBV literature databases were searched using a list of 26 keywords and their combinations that considered similar terms such as 'urban' and 'city' and 'metropolitan' as well as 'farming', 'gardening' and 'horticulture'. In the second phase, the collected literature was supplemented by relevant articles, books and documents referenced in the literature from the first phase. Altogether, 168 articles from peer-reviewed journals, magazines and books as well as documents including master theses and internet websites were incorporated into this study.

\section{Results: comparison of UA and PUA}

Production factors and framework conditions define the requirements for agricultural production. The majority of the literature surveyed associates them with field size, land availability and other spatial configurations as well as soil and site quality, social acceptance and economic success. They directly and indirectly influence the urban food system and the distribution and consumption patterns. When comparing UA with PUA, we examine the related spatial, ecological, economic and social conditions and how the operators of UA and PUA deal with them. Some generalised characteristics are thereby described in the process.

\section{Spatial factors: dealing with space under pressure}

\section{Location}

The different forms of UA, as discussed in the literature, are predominantly located in the densely settled areas of a city (e.g. Patel 1996; Lovell 2010; Rosol 2010). Community gardens and allotments, school gardens and rooftop gardens in particular are operated by urban dwellers from the neighbourhood, so that proximity to housing areas is assumed. In the case of a community garden in Philadelphia, for example, the gardeners live within half a mile $(0.8 \mathrm{~km})$ of the garden (Meenar and Hoover 2012).

PUA is situated in the urban fringe and urban periphery (e.g. Piorr et al. 2011). Originally, the areas of PUA were located outside the city (Steel 2009). Due to increasing urbanisation pressure and as the need to situate agriculture in close proximity to the market shrinks due to better transport and cooling possibilities, urban structures tend to permeate the agrarian landscape and transform it into a peri-urban entity. This development has been observed for example in Copenhagen (Swaffield and Primdahl 2006), the Rhein-Ruhr area in Germany (Mrohs 1979) and Worcester, Massachusetts (Lockeretz et al. 1987).

Considering the differences in urban development in the various regions and its dependency on topographic, historical, political and economic factors, it is evident that the locations of UA and PUA forms are not absolutely separated from each other by rigid borders. Instead, in many cases an overlapping zone must be assumed, as illustrated in Fig. 1. Because of this ambiguity, while location is a factor, it is hardly the only factor needed to differentiate between UA and PUA. Rural agriculture is located outside the urban or metropolitan areas.

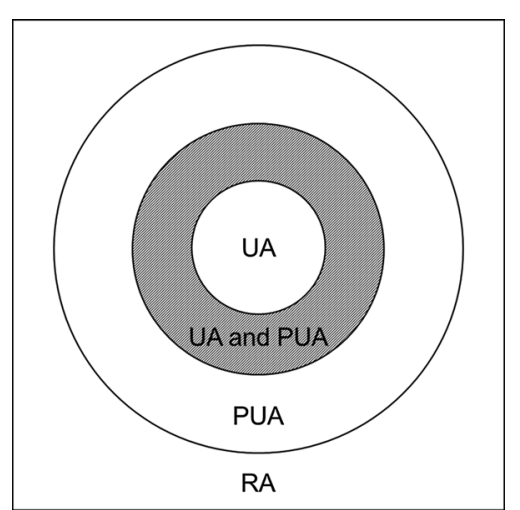

Fig. 1 Location of urban agriculture (UA), peri-urban agriculture (PUA) and rural agriculture (RA) within the urban-rural continuum 


\section{Scale of production sites}

We found little empirical data on the size of UA production area per garden or farm. Sample gardens and farms in cities are described as micro and small scale, with an area of less than 2000 square feet $(0.0186$ ha) up to 12.85 acres (5.2 ha) (Allen 2007; Dekking et al. 2007; Rosol 2011; Meenar and Hoover 2012; Bendt et al. 2013; Martin et al. 2014). In some cases, size results from the farming concept, such as in the case of small-plot intensive (SPIN) farms, where the suitable maximum size is defined as one acre (0.4 ha) (Christensen 2007). In many cases, limited availability of space determines the size of the production site. For example, small-scale gardening typically prevails on rooftops or in backyards, while in contrast, vacant lots can provide units of several hectares. These are exceptions, however, found in compact urban areas in shrinking cities or cities under structural transformation.

In contrast, the literature describes production-site units in peri-urban regions as professional farms of sizes ranging from $<2$ to 100 ha, with most farms usually near the lower end of this range (Geoffriau 2010; Zasada 2011, 2012; Martin et al. 2014). In the case of Worcester County, Massachusetts, many PUA operations are carried out on $<25$ acres (Brown and Carter 2003). Single field plots are much smaller, particularly because agricultural land in peri-urban areas is often fragmented (Swaffield and Primdahl 2006; van der Schans and Wiskerke 2012). Jarosz (2008) describes similar structures in North America. After urban growth drove the large, industrialised agricultural holdings from the peri-urban zones, small-scale farms remained, where they were left to address the urban demand for high quality and high value organic and local produce.

\section{Land use category}

In general, UA is performed on land that is not agriculturally zoned. In most countries in the Global North, there is no independent category for UA in municipal zoning plans, as agriculture was historically regarded as a "rural" activity by urban planners (Pothukuchi and Kaufman 1999). Consequently, UA is seldom protected or controlled, and land use conflicts are difficult to resolve (Castillo et al. 2013). Exceptions can be found in cities like Chicago (Cohen 2012) or Vancouver (Broadway and Broadway 2011), where UA is regulated as land use with certain restrictions (such as those applied to compost household waste, or other unique restrictions related to certain boroughs). Further exceptions can be found in the case of the European allotment gardens, which are regulated on various levels (Gröning 1996; Bendt et al. 2013).

Land used for UA activities is situated on non-agricultural spaces marked as private or public vacant lots (e.g.
Gibson 2005; Lovell 2010; Ackerman et al. 2014), in public parks (Buttery et al. 2008), on rooftops (e.g. Astee and Kishnani 2010; Ackerman et al. 2014), in backyard gardens (Blake and Cloutier-Fisher 2009) or indoors (Specht et al. 2014). Previous land uses were often related to industry and to infrastructure (Deelstra and Girardet 2001), housing (Schmelzkopf 1995), or recreation.

The agricultural land of PUA is generally a distinct land-use category in the zoning plans, and has often already been used for agricultural purposes for decades. Therefore, PUA farmers report fewer obstacles regarding zoning than UA practitioners (Castillo et al. 2013). Nevertheless, the zoning status does not protect agricultural land from being built upon. One aspect that often hampers the area's protection is the unclear or changing responsibilities of the various municipalities sharing the peri-urban area (Allen 2003), which can result in a lack of general planning (Zasada 2011). There are some examples where planners and municipalities developed strategies to protect agriculture in the peri-urban area, such as the finger plan in Copenhagen (Swaffield and Primdahl 2006), the Baix Llobregat Agricultural Park near Barcelona (Paül and McKenzie 2013) or the agricultural buffer zones in the US (Sullivan et al. 2004).

\section{Duration of land use contracts}

Limited land-use rights and illegal land use often come up in literature on UA (e.g. Saldivar-Tanaka and Krasny 2004; Balmer et al. 2005; Thibert 2012). UA carried out on vacant lots interrelates with ownership and the real estate market dynamics of cities. The example of community gardens in New York City (NYC) demonstrates the level of UA displacement as investment interest increases (Schmelzkopf 1995, 2002; Mees 2007). To remain open to further value-added developments, public and private land owners often tolerate UA only as an interim use (De Zeeuw et al. 2001; Lovell 2010). On the other hand, UA itself can contribute to the valorisation of urban areas. Increasing rental prices for neighbouring flats can serve as first indication of such valorisation in this regard (Voicu and Been 2008).

Nonetheless, there are examples of urban gardens and farms that have been located on the same plot of land for decades. Reasons for their persistence include regular extensions of the contract term and policy interventions that reflect changes in the strategic priorities for vacant lots [as was the case for community gardens in NYC (Schmelzkopf 2002; Eizenberg 2011)].

In PUA, farmers face similar problems related to urbanisation pressure on land availability. The land market responds to urban area demand with increasing land prices (Cavailhes and Wavresky 2003; Munton 2009), and even 
prime agricultural land is used for development (EEA 2006; Knowd et al. 2006). Many farmers do not own the land they cultivate, and PUA holdings often receive only short-term rental contracts (Munton 2009). This in turn affects the farms' investment level and survival strategies (Péron and Geoffriau 2007; Piorr et al. 2011).

\section{Legal status}

Historically, UA is an activity without a legal status. However, many cities in the US have passed specific ordinances permitting certain commercial, community, or non-profit agricultural activity. For example, municipalities such as Vancouver (Broadway and Broadway 2011), Cleveland (Grewal and Grewal 2012) and NYC (Mees and Stone 2012) have enacted laws regarding keeping livestock and zoning regulations for UA (McClintock et al. 2014). Masson-Minock and Stockmann (2010) and Castillo et al. (2013) found further need for regulation in UA in their case studies in Flint, Michigan, and in Chicago. For example, they regulated the construction of hoop houses and fences on public land, and access to water, electricity, garbage and waste water disposal. However, there are significant scalar and spatial variations regarding the legal status of urban agriculture.

Agricultural holdings, as prevailing in PUA, are legal entities that have to deal with specific agricultural laws and rights. On the one hand, they are allowed to receive agricultural subsidies (exceptions can exclude hobby farmers, for example Zasada et al. 2013). On the other hand, they are obliged to practise according to various legislation established due to previous experience with negative environmental impacts of intensive agriculture (Oenema 2004), and to protect consumer health by enforcing food safety standards along the whole food value chain (Henson and Caswell 1999, or for an overview see Ghaida et al. 2014). Legally binding standards and regulations exist at different levels, from the supra-national to the regional, and they often not only address agriculture, but also other businesses (like the Clean Water Act in the USA or the EU FFH Directive). In some of these laws, exceptions are made for certain agricultural enterprises (Copeland 2011). For instance, in the USA "right-to-farm" laws allow noise, odour or other nuisances that are legally prohibited for other industries. Lately, these exemptions have been challenged in court (Ikerd 2010).

\section{Spatial adaptation strategies}

As Prain and De Zeeuw (2007) have stated, the need and the opportunities for innovation are high in urban contexts. One innovative strategy in UA for dealing with scarcity is the concept of sharing space and resources. Community gardens are often associated with this concept because sharing tools and experience as well as collaborative gardening activities are important motivating factors for the people involved (Holland 2004). Another example is the concept of small-scale sharecropping or a shared backyard garden. This concept is based on an arrangement between a garden owner and a person who is interested in gardening (Blake and Cloutier-Fisher 2009).

A further innovative strategy in UA in dealing with the urban conditions is agriculture in and on buildings, where new spaces for food production are created (Besthorn 2013; Specht et al. 2014). Using vacant buildings or suitable rooftops, food is grown in spaces that are not typically designed for agricultural production. At a city level, the amount of land that could potentially be used for agriculture can be increased enormously with this approach (Buttery et al. 2008; Rodriguez 2009; Engelhard 2010; Ackerman 2011). While the number of rooftop farms is rising around the world, the vision of vertical farms, highrise buildings with various farming activities inside and on the roof or façade (Despommier 2010), has so far not been implemented (Specht et al. 2014).

Space-related adaptations have not been reported for PUA. Other forms of adaptation to the specific peri-urban conditions are described below. Figure 2 gives an overview of the differences and similarities regarding the spatial characteristic of UA and PUA.

\section{Ecological factors: dealing with site conditions}

\section{Soil use}

Besides growing in the ground, an often applied strategy of UA for dealing with the potential risk of contaminated urban soils is cultivation in raised beds on various substrates (Goldstein 2009; Lovell 2010; Ackerman 2011). Mees and Stone (2012) describe raised beds as a less expensive alternative to testing the soil. Another measure used to prevent plants from taking up soil contaminants is to change the topsoil (Buttery et al. 2008; Goldstein 2009).

A more fundamental form is the use of hydroponic or aquaponic techniques (Nelkin and Caplow 2007; Specht et al. 2014). Here, vegetables (for example) are grown in greenhouses in a nutrient solution. In addition to the advantage of controlled nutrient management (Schmierer et al. 2010), these innovative techniques are especially suitable to buildings, since the weight of the soil can endanger the buildings' stability (Hui 2011).

Compared to UA, PUA mainly uses local soil and therefore applies management practices related to sitespecific soil conditions. Traditionally, towns often developed in areas with comparably high soil fertility (Bryant and Johnston 1992; Lohrberg 2001). Soil nutrient status in 
Fig. 2 Spatial differences and common features of urban and peri-urban agriculture

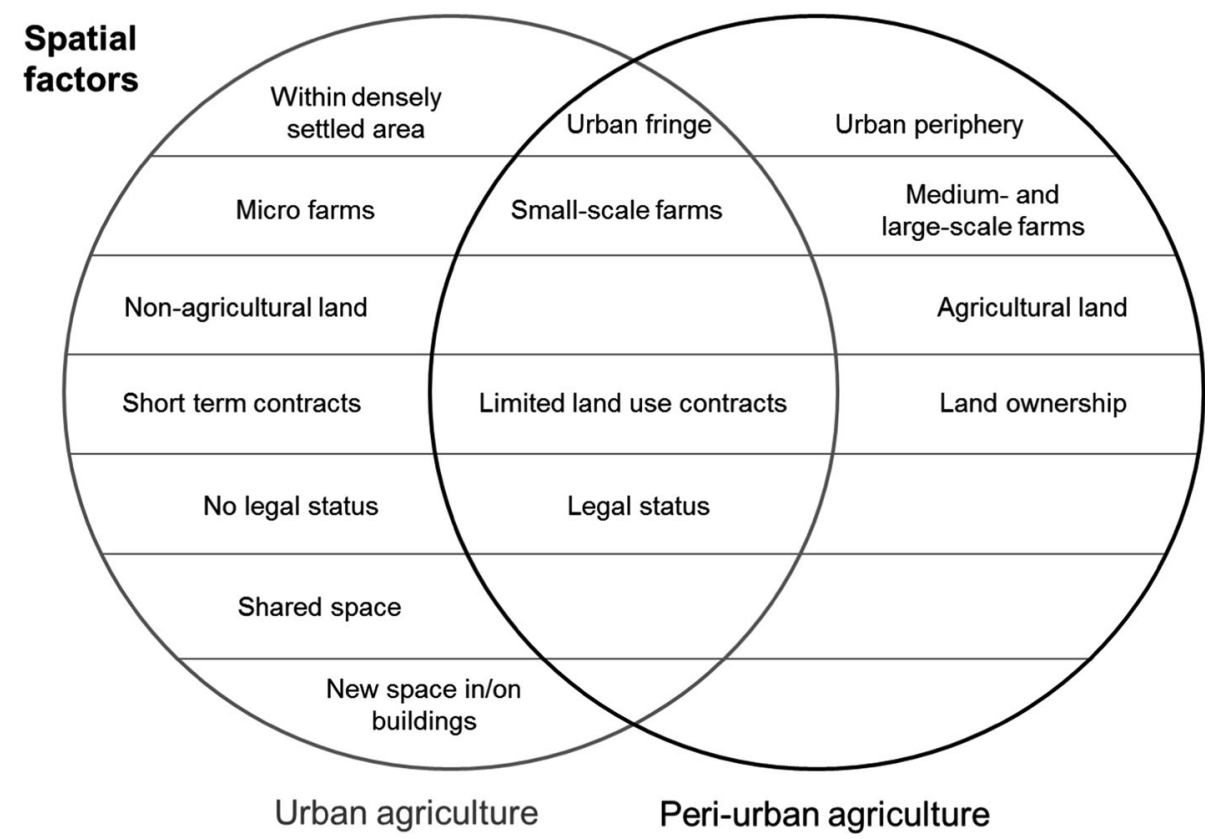

PUA is generally affected by the way in which it is farmed. Still, PUA can be negatively impacted by urban air pollution (Heimlich and Anderson 2001) or affected by other industries, such as mining close to urban areas (Arao et al. 2010). Soil-free cultivation is also applied within PUA in greenhouses either on substrate (Korthals Altes and van Rij 2013) or hydroponics, for example in the Greater London area (Garnett 2001).

\section{Recycling management}

Managing waste and utilising recycled materials from plant residues after harvest or from kitchen waste are key components of the organic nutrient supply of UA systems, as various case studies indicate (Deelstra and Girardet 2001; Ackerman 2011; Grewal and Grewal 2012; Mees and Stone 2012). While some authors emphasise the potential of UA to pioneer improved resource efficiency (Deelstra and Girardet 2001; Metcalf and Widener 2011; Grewal and Grewal 2012), others describe organic waste-management practices as an integrated part of the resource management in certain UA projects (Patel 1996; Allen 2007; Cohen et al. 2012; Mees and Stone 2012).

However, Murray et al. (2011) pointed to possible health risks related to the use of compost. They found that compost amendment in some cases increased the accumulation of heavy metals in lettuce and carrots, and recommend guidelines for compost application.

In the context of recycling practices, PUA does not differ from rural agriculture. While it remains unclear to what extent materials are recycled on-farm, the recycling of organic materials, such as manure or plant residues, is known to play a particularly important role for organic farms (IFOAM n/s).

Compost from municipal solid waste is increasingly used in agriculture, even though there are concerns about metal content (Hargreaves et al. 2008). In the European Union, almost $50 \%$ of the compost produced is used in agriculture, with $11 \%$ being used for horticulture and greenhouse production (Barth et al. 2008). But again, specific data for the peri-urban areas in the Global North is missing. Only Péron and Geoffriau (2007) mention the use of compost by vegetable farmers in the peri-urban areas of Paris and Lisbon.

\section{Water management}

The most commonly cultivated crops in UA are fruits and vegetables, both of which need a regular water supply during their vegetation period. Limited or irregular availability of rain water can make irrigation measures necessary, especially when cultivation takes place in raised beds or containers.

Water from hydrants (Ackerman 2011) and rainwater harvesting are two applied systems (Mees and Stone 2012). Other techniques for conserving water include low-budget drip irrigation systems, the reuse of water (such as greywater from households) and mulching strategies (Nolasco 2011).

Non-soil cultivation techniques such as aquaponic and hydroponic cultivation are considered efficient in their use of water because of the continuous reuse of water (Caplow 2009; Astee and Kishnani 2010).

In open field cultivation (particularly of fruit and vegetables), irrigation measures are often practised in PUA in 
warmer climates such as those found in Spain, France (Péron and Geoffriau 2007) and in the USA (Locascio 2005), as a protection measure against drought damage (Wittwer and Castilla 1995). Péron and Geoffriau (2007) observed innovative irrigation technologies, such as drip irrigation, solution recycling and wastewater irrigation (Barker et al. 2011) to cope with water shortages.

\section{Adaptation strategies to site conditions}

In the literature on UA, we found few examples of permanent or temporary greenhouses or hoop houses that extended the growing season or made crop production less vulnerable to cold snaps (Lovell 2010; Mees and Stone 2012). With these methods, a broader variety of vegetables can be grown and the plants can be propagated indoors. While UA greenhouse cultivation is applied in most cases without artificial radiation and temperature control, inhouse farming as a specific form of UA is dependent on full substitution of sunlight (Despommier 2010).

In PUA, intensive production schemes using greenhouses have also been introduced in order to produce all year round and with consistent quality (Wittwer and Castilla 1995). Korthals Altes and van Rij (2013) regard greenhouse cultivation as a typical peri-urban land use and examples can be found around Lisbon, Paris, Bordeaux and Lille (Péron and Geoffriau 2007), in the Lea Valley near London (Garnett 2001), around Copenhagen (Zasada et al. 2011) and Westland, NL near The Hague (Korthals Altes and van Rij 2013). Local site conditions can be complemented using extra light, heating, irrigation and artificial growing media in the greenhouses. The differences and similarities of UA and PUA regarding their ecological characteristics are summed up in Fig. 3.

\section{Social and economic factors: integration to society and market}

\section{Professionalism}

Community gardeners are usually local residents, migrants and children (Armstrong 2000; Gibson 2005; Mees 2007). Motivated by voluntary ideologies, activists often lack a professional agricultural education or even gardening skills. These skills are then often acquired in educational workshops provided by non-profit organisations and municipal administrations (Henderson and Hartsfield 2009).

Even UA practitioners who have an economic orientation do not necessarily draw from any formal agricultural education (e.g. Christensen 2007; Grün 2012). Instead, informal learning processes driven by experimentation, experience (Holland 2004; Bendt et al. 2013) and learningby-doing approaches are common in UA (Müller 2011). While traditional agricultural knowledge is often missing, urban producers may have knowledge that is important for innovation and adaptation to urban conditions, such as local knowledge about socio-economic dynamics and access to alternative resources (Prain and De Zeeuw 2007).

PUA farmers are mainly agricultural professionals who apply modern management practices and machinery (e.g. Andersson et al. 2009) and produce food for the market for profit. However, similarly to the majority of practitioners of UA, not all land managers in rural agriculture and PUA are professionals. Increasing numbers of so-called lifestyle
Fig. 3 Ecological differences and common features of urban and peri-urban agriculture

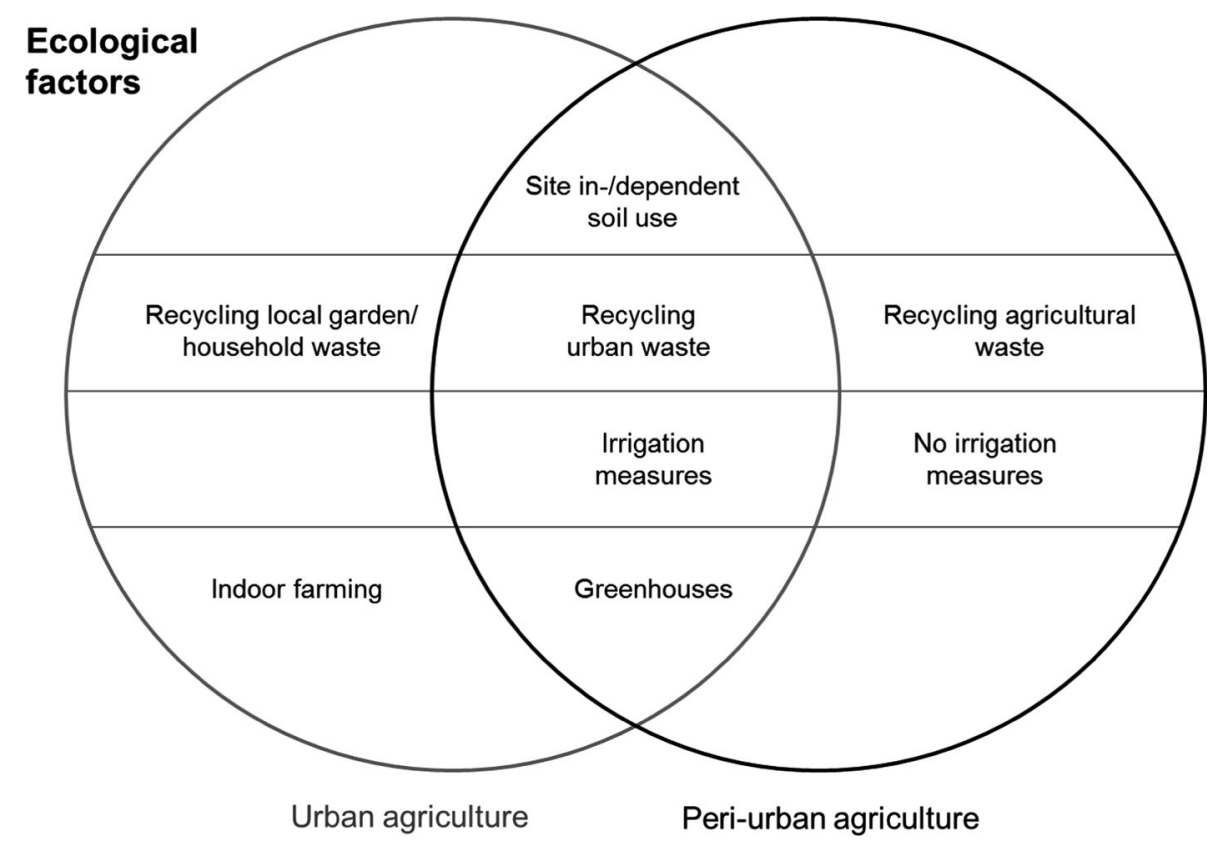


or hobby farmers have been observed (Primdahl and Kristensen 2011; Zasada 2011; Orsini 2013). These are often urbanites who have left a city to start farming as a leisure activity while generating their main income outside the farm (Primdahl and Kristensen 2011).

\section{Motivation}

The many motivations for UA documented in the literature are as diverse as the UA stakeholders and their livelihood strategies. Individual motivating factors are food provision, recreation, nature experience, exercise and health, as well as supplemental income (Armstrong 2000; Holland 2004; Bleasdale et al. 2011; Turner 2011; Cohen 2012). Observed benefits on the community level are community development (Holland 2004), beautification (Armstrong 2000) or education (Cohen et al. 2012).

PUA is mainly practised by professionals, so their motivation is mainly income generation. Exceptions to this are the lifestyle farmers, which is a term that encompasses part-time, hobby or retired farmers (Primdahl and Kristensen 2011; Zasada 2011).

\section{Network structures}

Networks are often described in terms of their internal learning processes (Barthel et al. 2010; Travaline and Hunold 2010; Bendt et al. 2013). They thus contribute to generating social capital (Alaimo et al. 2010; Firth et al. 2011) and can be a decisive success factor for a project itself (Buttery et al. 2008; Corrigan 2011; Meenar and Hoover 2012). As well as this, they can be an effective approach to solving land-use conflicts (Barthel et al. 2010).

The literature identifies different groups of stakeholders involved in UA initiatives ranging from regular and intensive participants to one-time visitors. Important stakeholder groups are umbrella or supporting organisations like trusts (Eizenberg 2011), food organisations (e.g. Baker 2004; Broadway and Broadway 2011) and advocacy groups (Baker 2004; Gibson 2005; Mees 2007), but also public institutions such as schools and universities (Armstrong 2000; Rosol 2010). Other public bodies involved include: municipal councils that offer supporting programmes (Levy 2008; Broadway 2009; Corrigan 2011); companies in public-private partnerships (Hess and Winner 2007); neighbours (Hess and Winner 2007; Buttery et al. 2008); visitors (Grün 2012) and volunteers (Armstrong 2000; Ackerman 2011). Cohen et al. (2012) distinguish four relevant groups in UA in NYC: farmers and gardeners, support organisations, funders, and government officials.

Farmers and landowners are by far the largest group of stakeholders considering PUA. Spatial proximity and conceptually designed opportunities offer further contact points between PUA farmers and other stakeholders, such as neighbours, visitors and active participants in farm-work concepts like pick-your-own, horse care or voluntary work in Community Supported Agriculture (CSA). If voluntary work is offered, it is also often organised by NGOs (Janssen 2010). Municipalities and their planners are the stakeholders that steer the development of the region, and there are networks for peri-urban regions' stakeholders, for example PURPLE (www.purple-eu.org) in Europe. However, to our knowledge, there are no special "peri-urban" farmer organisations apart from the general farmer organisations and associations dealing with specialised forms (e.g. horse keeping or organic farming). Péron and Geoffriau (2007) even criticise the lack of cooperatives among peri-urban vegetable farmers. Nevertheless, alternative food chains have established new producer-consumer links between the peri-urban and urban (Allen et al. 2003), such as CSA, direct sales to food cooperatives and restaurants and regular farmers' markets (Jarosz 2008). Urbanites from Amsterdam founded an association to reconnect with the peri-urban farmers and to establish "meaningful" relations (Le Grand and van Meekeren 2008), while at Ile-deFrance, some citizens and local authorities are attempting to preserve agriculture with 'agri-urban projects' (Vidal and Fleury 2008). In the Netherlands, there are several regional cooperative projects that safeguard PUA, enabled and supported by the European Union program LEADER+ (Le Grand and van Meekeren 2008).

\section{Distribution pathways}

When examining UA in Philadelphia, Meenar and Hoover (2012) identified three distribution channels. Firstly, informal distribution as self-consumption is presently the most-employed channel, whereby gardeners give away the produce to friends and acquaintances. Secondly, there are sales made via direct marketing over farm stands or CSA. The third most-employed distribution approach is to donate the produce to soup kitchens or emergency organisations. Even though the use of the three distribution channels varies from city to city, self-consumption or 'growing for subsistence' is generally found to be the main motivation and aim (e.g. Armstrong 2000; Bleasdale et al. 2011; Kortright and Wakefield 2011; Cohen et al. 2012). Selling the products is certainly an option for specific forms of UA but it is nevertheless subject to local and national laws. The study from Armstrong (2000), for example, found that allotment gardeners are by law prohibited from selling their produce in Germany (Bundeskleingartengesetz 1983). Charitable donations can be investigated separately as a relevant UA distribution path, but few case studies mention this approach (Corrigan 2011; Ackerman et al. 2014). 
The distribution paths of the crops in PUA are rather diverse. In contrast to UA, PUA products, either mass-market or high-value, potentially have a broader spatial reach, with some products sold on the global market (Vidal and Fleury 2008; Zasada 2012). Distribution via direct marketing like that carried out at farm gates and stands, farmers' markets, food-box schemes and Farm-to-School programmes have so far formed the focus of scholarly research. This has also examined sales made directly to restaurants, food cooperatives, CSA programs, pick-your-own schemes or selfharvest gardens (Ilbery 1991; Brown and Carter 2003; Vogl et al. 2004; Jarosz 2008; Kieninger et al. 2011).

\section{Diversification strategies}

There is some evidence in the literature for diversification strategies carried out within UA. In addition to gardening and production activities, social and cultural services such as day care (Dekking et al. 2007), gastronomic facilities (Grün 2012), readings or markets (Armstrong 2000; Grün 2012) occur. Ackerman (2011) refers to additional income opportunities from 'multiple revenue streams'. This includes direct marketing strategies to restaurants and institutions, as well as education and training services. Mbiba (2003) has demonstrated the potential for obtaining additional income by giving regular school lessons or offering after-school activities on city farms in London.

In PUA, two prevailing and contrary forms of adaptation have been observed (Zasada 2011). One form is specialisation in horticulture, which has often been linked to the intensification of production towards the higher price segment found within the scope of glasshouse vegetable production, ornamental plant growth and organic farming (van der Schans and
Wiskerke 2012). Extensification in the form of commodityoriented innovative business concepts like farm tourism, horse keeping, self-harvest and social farming makes up the other form observed (Beauchesne and Bryant 1999; Vogl et al. 2004; Kieninger et al. 2011; Zasada et al. 2013).

Diversification activities are numerous in PUA. In his study on PUA in the West Midlands, Ilbery (1991) listed those diversification measures as being (1) Direct marketing, (2) Accommodation, (3) Recreation (sports, events, etc.), (4) Processing and commercial activities (catering, cheese production, etc.), and (5) Passive (building lets, land lets, etc.). The findings from this section are summarised in Fig. 4.

\section{Discussion: current impact of UA and PUA on urban food security}

Discussing food security requires consideration of all the different levels of a food system as Pothukuchi (2004) described them: food production, processing, distribution and consumption.

Due to the diversity of UA and PUA as described above, the potential and actual contribution to sustainable urban food systems varies. These contributions are discussed below in light of their different activities within the four levels of a food system.

\section{Food production}

In an urban food system, food production includes aspects like quantity of food (Armar-Klemesu 2001; Brown and Carter 2003; Colasanti and Hamm 2010; Grewal and
Fig. 4 Socio-economic differences and common features of urban and peri-urban agriculture

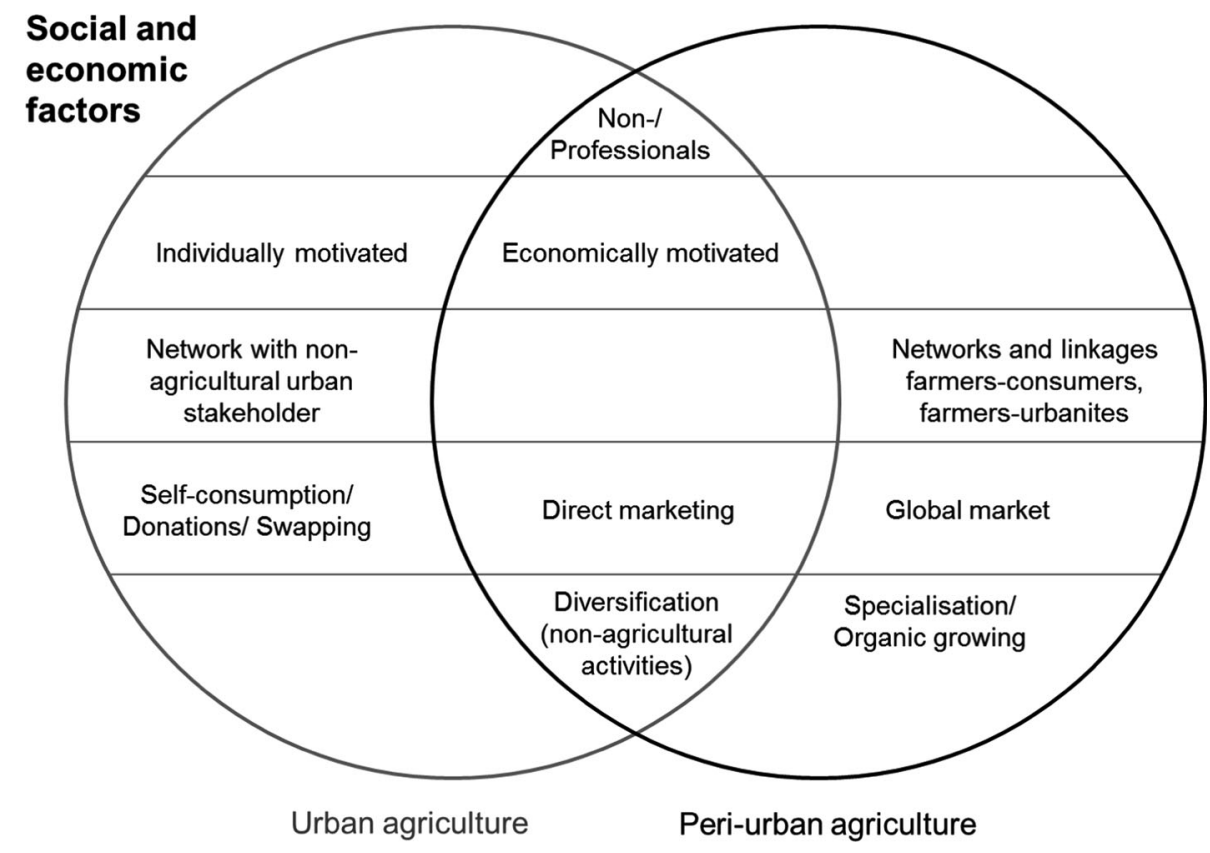


Grewal 2012; Ackerman et al. 2014), quality of food (Caputo 2012; Fernandez et al. 2013; Ackerman et al. 2014), the range of products (Armar-Klemesu 2001) and pest and contamination risks (Ackerman 2011; Lang and Barling 2012).

One important aspect in the discussion about food security is the amount of produce that can be provided by an agricultural system (Lang and Barling 2012). Higher yields can be expected per farm and season under PUA as a consequence of the availability of space, the application of technology and the level of professionalism involved (Martin et al. 2014). In contrast, yield potential and yield stability, the lack of a legal status, and the short-term contracts associated with UA all contribute to reduced quantities when compared to PUA. Both systems certainly produce yields that are not insignificant (e.g. Meenar and Hoover 2012; Algert et al. 2014). However, subsistence concepts prevail in UA, where the distribution channels are mainly either informal, or those pathways that have not yet been restricted. This then fundamentally limits the possibility of considering UA as a strategic method for food planning. Strategies geared towards increasing the amount of locally produced food and reducing dependence on the global food trade should therefore focus more narrowly on PUA.

Food production capacity is also determined by the range of products that can enter the food system. Considering UA and PUA together, Armar-Klemesu (2001, 105) stated that it "cannot be expected to satisfy the urban demand for staple crops like cereals and tubers." UA and PUA predominantly produce vegetables and high-value crops due to the market-access advantages for perishable goods. Local livestock products (animal products and byproducts such as meat, eggs or feathers) are rather associated with PUA than UA. It is therefore argued that PUA is indispensable if a broad range of locally produced, nutritionally adequate food is to be produced.

Quality is also another aspect of food security and production to consider. On the one hand, responsible pest control can improve agricultural quality levels (Müller 2011), but on the other hand, the perception of food quality is affected by aspects related to origin, trust, freshness and flavour (Kortright and Wakefield 2011). In the latter case, the perception of food quality is shaped by individual experiences related to access to fresh food (e.g. Block et al. 2012) and suspicions about the origin and quality of the products in grocery stores and supermarkets (e.g. Kortright and Wakefield 2011). UA is well-placed in this regard, as it provides a high level of transparency concerning the origin of the food and its production process. In the profit-oriented PUA, food quality is related to commercial qualities such as size, form and the standards of the production process of organic products. As in UA, the origin of food, locality and trust in the producer and the product are also important issues affected by the relation between the farmer and the consumer through direct marketing.

Some research has been carried out on pest and contamination risks and avoidance practices or plant nutrition standards within the framework of UA (Ackerman 2011; Säumel et al. 2012; Spliethoff et al. 2014). Due to the low levels of professionalism and the partly short-term involvement of stakeholders in gardening activities, it is unclear whether there exists an extensively applied, knowledge-based and responsible method of working with pesticides and fertilizers in respect to various species, soil types and nutrient contents, which is important for human health and ecosystem services. Even if workshops on composting and other gardening practices are available (e.g. Henderson and Hartsfield 2009; Mees and Stone 2012; Grün 2012), individual decisions and perceptions may dominate the application of chemical and organic substances.

PUA is predominantly carried out by professional agriculturalists, and therefore an extensive knowledge of management techniques can be assumed. Like all agricultural holding operators, peri-urban farmers are tied to the national or transnational food safety legislations with threshold controls over hormones, pesticides and hygiene levels (Trienekens and Zuurbier 2008). Regular inspections are conducted in organic-certified production processes (Scialabba and Hattam 2002). Contaminants or other pollutants cannot be precluded from the PUA process, but the legal status as agricultural land and liability in the monitoring and control system of food trade makes potential contamination traceable and accountable. In summary, the issue of pest and contamination risk is an under-investigated issue in UA and hardly predictable. Integrating UA produce into the urban food system would require greater knowledge of the applied practices and control mechanisms to be installed.

\section{Food processing}

Food processing creates food that is both more durable and more lucrative. It is a common step in professional agriculture, which can lead to tremendous amounts of food waste, as shown from figures by Gustavsson et al. (2011) and Buzby and Hyman (2012). Selection, post-harvesting and storage as well as processing losses can be as high as $25 \%$ within the food chain from farm to fork. As produce from UA is mainly directly consumed or marketed, this kind of food waste is especially an issue for some of the PUA farms that focus on processed food. 


\section{Food distribution}

In an urban food system, food distribution includes aspects of food access (Macias 2008; Block et al. 2012; Meenar and Hoover 2012; Fernandez et al. 2013) and food miles (Brown and Carter 2003).

Distribution pathways as discussed above suggest that different societal groups and individuals are driven by different motivations when seeking access to food provided by UA and PUA. Food produced in UA is usually sought by those involved in the associations and communities producing the food and supporting UA, namely the gardeners and their families. The socio-economic situation of the gardeners' households cannot be readily identified, however. Often, low-income households are identified as participants in community gardening in North America (Schmelzkopf 1995; Armstrong 2000; Lovell 2010; Bleasdale et al. 2011; Fernandez et al. 2013). Other studies have identified medium to high-income households (Smith et al. 2013) or all income levels (Kortright and Wakefield 2011). How UA contributes to food justice is difficult to determine. Meenar and Hoover (2012) have found that UA is perceived as a predominantly 'white' activity, while in other studies, the participants have been described as having different racial backgrounds (e.g. Airriess and Clawson 1994; Armstrong 2000; Mees 2010). As the food justice movement tries to address the food access disparities, especially in food deserts, urban agriculture is not their only solution. Whether they succeed and in how far they are linked to the food sovereignty movement coming from the Global South has recently been discussed (e.g. Alkon and Mares 2012; Block et al. 2012).

PUA produces for many markets, from the local community right through to the global market, and the products thus have a greater potential reach than UA products. According to the study carried out by Macias (2008) on organic farms and their customers, direct marketing to restaurants and grocery stores mainly serves higher-income clientele. This is not the case with farmers' markets, which target diverse population groups. When considering the aspect of limited mobility, especially applicable to low income earners, it is important to understand that many do not have the time to buy produce from a farmers' market, since they may have two or more jobs. It must be assumed that farmers' markets can provide food only for certain segments of the population. Which population segments benefit from farmers' markets depends on the city or neighbourhood.

'Food miles' as a term means the distance that food has to travel from the farm to the plate (Jansma et al. 2012). UA and PUA produce is predominantly distributed unprocessed, which reduces food miles, because the food does not need to travel to an extra processing unit. The research on food miles is scant. Denny (2012) has calculated that tomato production in UA can help reduce $\mathrm{CO} 2$ emissions during the growing season. Using a Life Cycle Assessment, Kulak et al. (2013) has also shown significant greenhouse gas savings for CSA in nearly all crops when compared to conventional distribution systems. However, those differences vary greatly between different crops, and so it is not possible to make general statements on the impact that UA and PUA have on food miles and greenhouse gas emissions. Nevertheless, based on the results from the available studies, it can be said that: "community farms and other forms of UA should not be seen as an ultimate solution" in Western Europe (Kulak et al. 2013, 76).

\section{Food consumption}

It is important to consider how UA and PUA affect consumption patterns (Armar-Klemesu 2001; Brown and Carter 2003; Lang and Barling 2012) and the awareness of food waste (Pothukuchi 2004) when investigating the urban food system.

Only a limited number of studies have investigated whether UA and PUA influence food consumption patterns at all. Alaimo et al. (2008) and Carney et al. (2011) explored the relation of UA and fruit and vegetable intake levels among the participants of community gardening projects, just as Kortright and Wakefield (2011) did for residential food production. Turner (2011) investigated how awareness of seasonal products was affected. A high interest in the products can be assumed for those participating in UA and its associated self-consumption patterns. With the amount of time and labour invested into caring for the plants throughout the season, the amount of wasted vegetables and fruit from the gardens is reduced, as Kortright and Wakefield (2011) concluded. It is more difficult to assume that less food waste in general occurs among UA participants, however.

When considering the influence of PUA-derived produce on general consumption patterns (especially those associated with the customers of farmers' markets) it can be assumed that there is a higher awareness of healthy food. This is because farmers' markets predominantly offer unprocessed fresh food. Furthermore, locally produced and highly perishable food is often fresher due to the shorter transportation distances. Accordingly, the waste of fresh produce from PUA is less likely, due to the higher levels of professionalism in PUA short food chains. To date, few studies have been carried out on that issue. CSA explicitly aims to generate less food waste by having members commit to accepting produce that does not fully meet marketing standards because of size, shape, etc. However, there is no evidence published confirming that CSA brings about less food waste from farm to plate. 


\section{Conclusion}

Regarding the Global South, the zones where PUA and UA spatially overlap seem much larger compared to the Global North. This is due to higher production intensity within cities and a large amount of non-professional, more subsistence-focused agriculture in the peri-urban areas. This is a very generalised view, and does not take into account the specific differences from country to country or even city to city. Also in the Global South, UA and PUA should be further investigated and their respective potentials-apart from food provision- promoted. Meanwhile, to strengthen urban food security, some of the adaptation strategies already applied in the Global North can be applied in the Global South and vice versa-like the intensive Cuban cultivation techniques now practised in urban farms in Berlin, Germany.

In the Global North, considering UA and PUA not only as agricultural activity in urban or peri-urban space, but in detail as systems adapted to specific and distinct spatial, ecological, social and economic conditions, more differences than similarities between the two become visible. Thus, UA is micro- to small-scale agriculture that cultivates non-agricultural land predominantly within the densely settled area of cities. Motivation generally comes from the individual, and as such the operations are run by non-professional activists with short distribution pathways such as own consumption, charitable donations and direct marketing. Compared to this, PUA is small- to large-scale agriculture that cultivates agricultural land predominantly at the fringes of cities. It is first and foremost economically motivated and is operated by professionals with medium to large distribution pathways from direct marketing up to global value chains. The two systems are similar in terms of their adaptation strategies to ecological conditionsusing water management strategies-and to socio-economic conditions-diversifying with non-agricultural offers. As a result, their actual contribution to providing culturally acceptable, nutritionally adequate food at all times varies significantly.

UA predominantly meets household-level requirements. This means that the radius of distribution is predominantly limited to family, friends and the neighbourhood, especially because of individual decisions and lifestyles and lower quantities produced in gardens. Thus, UA only manages to produce culturally acceptable food for a limited target group that is not generally the group of people most in need. It is more difficult to estimate UA's contribution to providing nutritionally adequate food. On the one hand, practising agriculture promotes a perception of healthy food and an increased intake of fresh products. On the other hand, pest and contamination risks are unrateable, because of the missing legal status, rules and control mechanisms for UA. The aspect of providing food at all times is actually not met by UA. Often, gardens and farms inside the cities are interim uses, threatened by economically more lucrative land uses. Individually, limitations in providing food at all times are influenced by a low level of processing and the low level of professionalism. Indeed, there are enterprises and organisations that experiment with indoor farming or the extension of growing periods, but their output is still comparably low.

As a consequence, to improve the impact of UA for urban food security, it is important to pursue two different paths. First, incentives to increase the number of economically motivated professionals in UA should be implemented, because longevity and stability of UA cannot be based on individual motivation and the private gardeners' personal situations alone. The second path to increased food security with UA aims to provide more fresh food at the household level, so that people in food deserts or needy people get the opportunity to supplement their diet with fresh and healthy food.

With PUA, the aim of providing the urban population with culturally acceptable and nutritionally adequate food is getting closer. Especially, direct marketing strategies with comparably short transportation routes guarantee seasonal, regional, fresh and often organic food, although it only meets the needs of those customers who have access to direct marketing pathways and who are interested in unprocessed products. PUA performs well in providing nutritionally adequate food and, by providing animal products, it delivers a wider range of products than UA. Moreover, there are existing standards and controls to avoid pest and contamination risks. Currently, the conditions of PUA to provide food at all times are better than in UA. This is because of the professionalism and the utilisation of practices that extend the growing season, as well as a comparatively higher stability of the agricultural unit. Nevertheless, the pressure of growing cities on agricultural land in the fringe cannot be neglected, nor can the shift away from food production to other services.

To improve the contribution of PUA to urban food security, this urban pressure has to be regulated and controlled. Priority zones for PUA can be an effective planning instrument that can provide more security and stability for peri-urban farmers. Additionally, diversification of the distribution pathways of PUA is necessary to utilise its whole potential, such as implementing production on demand for canning factories.

All in all, various measures regarding many different social and economic levels are necessary to achieve urban food security, ranging from changing the individual perception of food and nutrition to a basic right to fresh and 
healthy food and water. Certainly, to build up an urban food system whose goal is urban food security, UA and PUA and their specific potentials must play an important part.

Acknowledgments We would like to thank the three anonymous referees and the editor of the journal for their valuable comments and suggestions. As this study was written within the research project "Innovations Analysis of Urban Agriculture" (INNSULA), we would also like to thank the German Federal Ministry of Education and Research (BMBF) for funding the project and the supporting institution VDI/VDE-IT.

Open Access This article is distributed under the terms of the Creative Commons Attribution 4.0 International License (http:// creativecommons.org/licenses/by/4.0/), which permits unrestricted use, distribution, and reproduction in any medium, provided you give appropriate credit to the original author(s) and the source, provide a link to the Creative Commons license, and indicate if changes were made.

\section{References}

Ackerman, K. 2011. The potential for urban agriculture in New York City: Growing capacity, food security, and green infrastructure. New York: Columbia University.

Ackerman, K., M. Conard, P. Culligan, R. Plunz, M.-P. Sutto, and L. Whittinghill. 2014. Sustainable food systems for future cities: The potential of urban agriculture. The Economic and Social Review 45(2): 189-206.

Airriess, C.A., and D.L. Clawson. 1994. Vietnamese market gardens in New Orleans. The Geographical Review 84(1): 16-31.

Alaimo, K., E. Packnett, R.A. Miles, and D.J. Kruger. 2008. Fruit and vegetable intake among urban community gardeners. Journal of Nutrition Education and Behavior 40(2): 94-101.

Alaimo, K., T. Reischl, and J. Ober Allen. 2010. Community gardening, neighborhood meetings, and social capital. Journal of Community Psychology 38(4): 497-514.

Algert, S.J., A. Baameur, and M.J. Renvall. 2014. Vegetable output and cost savings of community gardens in San Jose, California. Journal of the Academy of Nutrition and Dietetics 114(7): 1072-1076.

Alkon, A.H., and T.M. Mares. 2012. Food sovereignty in US food movements: Radical visions and neoliberal constraints. Agriculture and Human Values 29(3): 347-359.

Allen, A. 2003. Environmental planning and management of the periurban interface: Perspectives on an emerging field. Environment and Urbanization 15(1): 135-148.

Allen, E.R. 2007. Urban agriculture as a social justice change agent and economic engine. Urban Agriculture Magazine 19: 49-51.

Allen, P., M. FitzSimmons, M. Goodman, and K. Warner. 2003. Shifting plates in the agrifood landscape: the tectonics of alternative agrifood initiatives in California. Journal of Rural Studies 19(2003): 61-75.

Andersson, K., E. Eklund, and M. Lehtola. 2009. Farmers, businessmen or green entrepreneurs? Producers of new rural goods and services in rural areas under urban pressure. Journal of Environmental Policy \& Planning 11(1): 29-43.

Antrop, M. 2000. Changing patterns in the urbanized countryside of Western Europe. Landscape Ecology 15(3): 257-270.

Arao, T., S. Ishikawa, M. Murakami, K. Abe, Y. Maejima, and T. Makino. 2010. Heavy metal contamination of agricultural soil and countermeasures in Japan. Paddy and Water Environment 8(3): $247-257$.
Armar-Klemesu, M. 2001. Urban agriculture and food security, nutrition and health. In Growing cities, growing food: Urban agriculture on the policy agenda, ed. N. Bakker, M. Dubbeling, S. Gündel, U. Sabel-Koschella, and H. De Zeeuw, 99-117. Feldafing: DSE/Zentralstelle für Ernährung und Landwirtschaft.

Armstrong, D. 2000. A survey of community gardens in upstate New York: Implications for health promotion and community development. Health and Place 6: 319-327.

Astee, L.Y., and N.T. Kishnani. 2010. Building integrated agriculture: Utilising rooftops for sustainable foodcrop cultivation in Singapore. Journal of Green Building 5(2): 105-113.

Baker, L. 2004. Tending cultural landscapes and food citizenship in Toronto's community gardens. The Geographical Review 94(3): 305-325.

Balmer, K., J. Gill, H. Kaplinger, J. Miller, M. Peterson, A. Rhoads, P. Rosenbloom, and T. Wall. 2005. The diggable city-Making urban agriculture a planning priority. Prepared for the City of Portland, Oregon. Portland, OR: Nohad A. Toulan School of Urban Studies and Planning.

Barker, F., R. Faggian, and A.J. Hamilton. 2011. A History of wastewater irrigation in Melbourne, Australia. Journal of Water Sustainability 1(2): 31-50.

Barth, J., F. Amlinger, E. Favoino, S. Siebert, B. Kehres, R. Gottschall, M. Bieker, A. Löbig, and W. Bidlingmaier. 2008. Compost production and use in the EU. Weimar: ORBIT e.V.I European Compost Network ECN.

Barthel, S., C. Folke, and J. Colding. 2010. Social-ecological memory in urban gardens: Retaining the capacity for management of ecosystem services. Global Environmental Change 20(2): 255-265.

Beauchesne, A., and C. Bryant. 1999. Agriculture and innovation in the urban fringe: The case of organic farming in Quebec, Canada. Tijdschrift voor Economische en Sociale Geografie 90(3): 320-328.

Beilin, R., and A. Hunter. 2011. Co-constructing the sustainable city: How indicators help us "grow" more than just food in community gardens. Local Environment 16(6): 523-538.

Bendt, P., S. Barthel, and J. Colding. 2013. Civic greening and environmental learning in public-access community gardens in Berlin. Landscape and Urban Planning 109(1): 18-30.

Besthorn, F.H. 2013. Vertical farming: Social work and sustainable urban agriculture in an age of global food crises. Australian Social Work 66(2): 187-203.

Blake, A., and D. Cloutier-Fisher. 2009. Backyard bounty: Exploring the benefits and challenges of backyard garden sharing projects. Local Environment 14(9): 797-807.

Bleasdale, T., C. Crouch, and S. Harlan. 2011. Community gardening in disadvantaged neighborhoods in Phoenix, Arizona: Aligning programs with perceptions. Journal of Agriculture, Food Systems, and Community Development 1(3): 99-114.

Block, D.R., N. Chávez, E. Allen, and D. Ramirez. 2012. Food sovereignty, urban food access, and food activism: Contemplating the connections through examples from Chicago. Agriculture and Human Values 29(2): 203-215.

Bohn, K., and A. Viljoen. 2010. The edible city: Envisioning the continuous productive urban landscape (CPUL). Field: A Free Journal for Architecture 4(1): 149-161.

Broadway, M. 2009. Growing urban agriculture in North American cities: The example of Milwaukee. Focus on Geography 52(3): 23-30.

Broadway, M., and J.M. Broadway. 2011. Green dreams: Promoting urban agriculture and the availability of locally produced food in the Vancouver metropolitan area. Focus on Geography 54(1): $33-41$.

Brown, K.H., and A. Carter. 2003. Urban agriculture and community food security in the United States: Farming from the city centre 
to the urban fringe. A Primer Prepared by the Community Food Security Coalitiońs North American Urban Agriculture Committee. Venice California.

Bryant, C.R. 1997. L'agriculture périurbaine: l'économie politique d'un espace innovateur. Cahiers Agricultures 6: 125-130.

Bryant, C.R., and T.R.R. Johnston. 1992. Agriculture in the city's countryside. Toronto: University of Toronto Press.

Bryld, E. 2003. Potentials, problems, and policy implications for urban agriculture in developing countries. Agriculture and Human Values 20(1): 79-86.

Bundeskleingartengesetz. 1983. BKleingG (Federal law of allotment gardens in Germany). 28.02.1983. BGB1 I 1983:210.

Buttery, C., T. Leach, C. Miller, and B. Reynolds. 2008. Edible Cities: A report of a visit to urban agriculture projects in the USA. London: A Sustain Publication.

Buzby, J.C., and J. Hyman. 2012. Total and per capita value of food loss in the United States. Food Policy 37(5): 561-570.

Cabannes, Y. 2006. Financing and investment for urban agriculture. In Cities farming for the future: Urban agriculture for green and productive cities, ed. R. van Veenhuizen, 87-123. Ottawa, Silang, Philippines: RUAF Foundation, IDRC and IIRR.

Caplow, T. 2009. Building integrated agriculture: Philosophy and practice. In Urban Futures 2030. Visionen künftigen Städtebaus und urbaner Lebensweisen. ed. Heinrich-Böll-Stiftung. Schriften Zur Ökologie 5:48-51.

Caputo, S. 2012. The purpose of urban food production in developed countries. In Sustainable food planning, ed. A. Viljoen, and J.S.C. Wiskerke, 259-270. Wageningen: Wageningen Academic Publishers.

Carney, P.A., J.L. Hamada, R. Rdesinski, L. Sprager, K.R. Nichols, B.Y. Liu, J. Pelayo, M.A. Sanchez, and J. Shannon. 2011. Impact of a community gardening project on vegetable intake, food security and family relationships: A community-based participatory research study. Journal of Community Health 37(4): 874-881.

Castillo, S.R., C.R. Winkle, S. Krauss, A. Turkewitz, C. Silva, and E.S. Heinemann. 2013. Regulatory and other barriers to urban and peri-urban agriculture: A case study of urban planners and urban farmers from the greater Chicago metropolitan area. Journal of Agriculture, Food Systems, and Community Development 3(3): 155-166.

Cavailhes, J., and P. Wavresky. 2003. Urban influences on periurban farmland prices. European Review of Agriculture Economics 30(3): 333-357.

Christensen, R. 2007. SPIN farming: Improving revenues on sub-acre plots. Urban Agriculture Magazine 19: 25-26.

Cohen, N. 2012. Planning for urban agriculture: Problem recognition, policy formation, and politics. In Sustainable food planning, ed. A. Viljoen, and J.S.C. Wiskerke, 103-114. Wageningen: Wageningen Academic Publishers.

Cohen, N., K. Reynolds, and R. Sanghvi. 2012. Five borough farm: Seeding the future of urban agriculture in New York City, ed. J. Chou. New York: Design Trust for Public Space.

Colasanti, K.J.A., and M.W. Hamm. 2010. Assessing the local food supply capacity of Detroit, Michigan. Journal of Agriculture, Food Systems and Community Development 1(2): 41-58.

Copeland, C. 2011. Animal waste and hazardous substances: Current laws and legislative issues. 7-5700. CRS Report for Congress. Washington, DC: Congressional Research Service.

Corrigan, M.P. 2011. Growing what you eat: Developing community gardens in Baltimore, Maryland. Applied Geography 31(4): 1232-1241.

De Bon, H., L. Parrot, and P. Moustier. 2010. Sustainable urban agriculture in developing countries: A review. Agronomy for Sustainable Development 30(1): 21-32.
Deelstra, T., and H. Girardet. 2001. Urban agriculture and sustainable cities. In Growing cities, growing food: Urban agriculture on the policy agenda, ed. N. Bakker, M. Dubbeling, S. Gündel, U. Sabel-Koschella, and H. De Zeeuw, 43-65. Feldafing: DSE/ Zentralstelle für Ernährung und Landwirtschaft.

Dekking, A., J.E. Jansma, and A.J. Visser. 2007. Urban agriculture guide. Urban agriculture in the Netherlands under the magnifying glass. Lelystad: Wageningen University Applied Plant Research.

Denny, G.M. 2012. Urban agriculture and seasonal food prints: An LCA study of tomato production and consumption in UK. In Sustainable food planning, ed. A. Viljoen, and J.S.C. Wiskerke, 323-336. Wageningen: Wageningen Academic Publishers.

Despommier, D. 2010. The vertical farm: Feeding the world in the 21st century. New York: Thomas Dunne Books.

De Zeeuw, H., S. Guendel, and H. Waibel. 2001. The integration of agriculture in urban policies. In Growing cities, growing food: Urban agriculture on the policy agenda, ed. N. Bakker, M. Dubbeling, S. Gündel, U. Sabel-Koschella, and H. De Zeeuw, 161-180. Feldafing: DSE/Zentralstelle für Ernährung und Landwirtschaft.

De Zeeuw, H., R. Van Veenhuizen, and M. Dubbeling. 2011. The role of urban agriculture in building resilient cities in developing countries. The Journal of Agricultural Science 1(1): 1-11.

Dubbeling, M., and G. Merzthal. 2006. Sustaining urban agriculture requires the involvement of multiple stakeholders. In Cities farming for the future: Urban agriculture for green and productive cities, ed. R. van Veenhuizen, 19-51. Ottawa; Silang, Philippines: RUAF Foundation, IDRC and IIRR.

Dubbeling, M., R. van Veenhuizen, and H. de Zeeuw. 2010. Cities, poverty and food: Multi-stakeholder policy and planning in urban agriculture. Rugby: Practical Action Publishing.

EEA. 2006. Urban sprawl in Europe: The ignored challenge. 10/2006. EEA Report. Copenhagen: European Environment Agency.

Eizenberg, E. 2011. The changing meaning of community space: Two models of NGO management of community gardens in New York City. International Journal of Urban and Regional Research 7. doi:10.1111/j.1468-2427.2011.01065.x. Accessed 8 Sept 2011.

Engelhard, B. 2010. Rooftop to tabletop: Repurposing urban roofs for food production. Master Thesis. Washington: University of Washington.

FAO, ed. 2007. Profitability and sustainability of urban and periurban agriculture.

Fernandez, M., K. Goodall, M. Olson, and E. Mendez. 2013. Agroecology and alternative agrifood movements in the United States: Towards a sustainable agrifood system. Journal of Sustainable Agriculture 37(1): 115-126.

Ferris, J., C. Norman, and J. Sempik. 2001. People, land and sustainability: Community gardens and the social dimension of sustainable development. Social Policy 35(5): 559-568.

Firth, C., D. Maye, and D. Pearson. 2011. Developing "community" in community gardens. Local Environment 16(6): 555-568.

Garnett, T. 2001. Urban agriculture in London: Rethinking our food economy. In Growing cities, growing food: Urban agriculture on the policy agenda, ed. N. Bakker, M. Dubbeling, S. Gündel, U. Sabel-Koschella, and H. De Zeeuw, 477-500. Feldafing: DSE/Zentralstelle für Ernährung und Landwirtschaft.

Geoffriau, E. 2010. Assessment of periurban vegetable production in France. Acta Horticulturae 881(1): 85-90.

Ghaida, T.A., H.E. Spinnler, Y. Soyeux, T. Hamieh, and S. Medawar. 2014. Risk-based food safety and quality governance at the international law, EU, USA, Canada and France: Effective system for Lebanon as for the WTO accession. Food Control 44: 267-282. 
Gibson, K.E. 2005. "11,000 vacant lots, why take our garden plots?" Community garden preservation strategies in New York City's gentrified Lower East Side. In Rights to the city, 3:353-366. Home of Geography Publication Series. Rome: Societa Geografica Italiana.

Goldstein, N. 2009. Vacant Lots sprout urban farms. BioCycle 50(10): 24-26.

Grewal, S.S., and P.S. Grewal. 2012. Can cities become self-reliant in food? Cities 29(1): 1-11.

Gröning, G. 1996. Politics of community gardening in Germany. In Branching out: Linking communities through gardening. Paper presented at the 1996 Annual Conference of the American Gardening Association (ACGA). Montréal, Canada: American Gardening Association (ACGA).

Guitart, D., C. Pickering, and J. Byrne. 2012. Past results and future directions in urban community gardens research. Urban Forestry and Urban Greening 11(4): 364-373.

Gustavsson, J., C. Cederberg, U. Sonesson, R. van Otterdijk, and A. Meybeckl. 2011. Global food losses and food waste: Extent, causes and prevention. Rome: FAO.

Hamilton, A.J., K. Burry, H.-F. Mok, S.F. Barker, J.R. Grove, and V.G. Williamson. 2014. Give peas a chance? Urban agriculture in developing countries: A review. Agronomy for Sustainable Development 34(1): 45-73.

Hargreaves, J., M. Adl, and P. Warman. 2008. A review of the use of composted municipal solid waste in agriculture. Agriculture, Ecosystems \& Environment 123(1-3): 1-14.

Heimlich, R.E. 1989. Metropolitan agriculture: Farming in the city's shadow. Journal of the American Planning Association 55(4): 457-466.

Heimlich, R.E., and W. Anderson. 2001. Development at the urban fringe and beyond: Impacts on agriculture and rural land. Agricultural Economic Report 803. Washington, DC: Economic Research Service, U.S. Department of Agriculture.

Henderson, B.R., and K. Hartsfield. 2009. Is getting into the community garden business a good way to engage citizens in local government? National Civic Review 98: 12-17.

Henson, S., and J. Caswell. 1999. Food safety regulation: An overview of contemporary issues. Food Policy 24(6): 589603.

Hess, D., and L. Winner. 2007. Enhancing justice and sustainability at the local level: Affordable policies for urban governments. Local Environment 12(4): 379-395.

Holland, L. 2004. Diversity and connections in community gardens: A contribution to local sustainability. Local Environment 9(3): 285-305.

Howe, J. 2002. Planning for urban food: The experience of two UK cities. Planning Practice and Research 17(2): 125-144.

Hui, S.C.M. 2011. Green roof urban farming for buildings in highdensity urban cities. Paper presented at World Green Roof Conference, March 18-21, Hainan, China.

IFOAM. 2005. Principles of organic agriculture. Bonn: International Federation of Organic Agriculture Movements (IFOAM) Head Office. http://www.ifoam.bio/sites/default/files/poa_english_ web.pdf. Accessed May 2015.

Ikerd, J. 2010. Zoning considerations for urban and peri-urban agriculture. Journal of Agriculture, Food Systems, and Community Development 1(2): 5-7.

Ilbery, B.W. 1991. Farm diversification as an adjustment strategy on the urban fringe of the West Midlands. Journal of Rural Studies 7(3): 207-218.

Iles, J. 2005. The social role of community farms and gardens in the city. In Continuous productive urban landscapes: Designing urban agriculture for sustainable cities, ed. A. Viljoen, K. Bohn, and J. Howe, 82-88. Amsterdam: Architectural Press.
International Federation of Red Cross and Red Crescent Societies. 2013. Humanitarian impacts of the economic crisis in Europe. Genf, Budapest: IFRC and RCS.

Jansma, J.E., W. Sukkel, E.S.C. Stilma, A.C. Van Oost, and A.J. Visser. 2012. The impact of local food production on food miles, fossil energy use and greenhouse gas emission: The case of the Dutch city of Almere. In Sustainable food planning, ed. A. Viljoen, and J.S.C. Wiskerke, 307-321. Wageningen: Wageningen Academic Publishers.

Janssen, B. 2010. Local food, local engagement: Communitysupported agriculture in Eastern Iowa. Culture and Agriculture 32(1): 4-16.

Jarosz, L. 2008. The city in the country: Growing alternative food networks in Metropolitan areas. Journal of Rural Studies 24(3): 231-244.

Kieninger, P.R., E. Yamaji, and M. Penker. 2011. Urban people as paddy farmers: The Japanese Tanada ownership system discussed from a European perspective. Renewable Agriculture and Food Systems 26(4): 328-341.

Knowd, I., D. Mason, and A. Docking. 2006. Urban agriculture: The new frontier. Paper presented at the planning for food seminar, 21 June 2006. Vancouver, Canada.

Korthals Altes, W.K., and E. van Rij. 2013. Planning the horticultural sector: Managing greenhouse sprawl in the Netherlands. Land Use Policy 31: 486-497.

Kortright, R., and S. Wakefield. 2011. Edible backyards: A qualitative study of household food growing and its contributions to food security. Agriculture and Human Values 28: 39-53.

Kremer, P., and T.L. DeLiberty. 2011. Local food practices and growing potential: Mapping the case of Philadelphia. Applied Geography 31: 1252-1261.

Kulak, M., A. Graves, and J. Chatterton. 2013. Reducing greenhouse gas emissions with urban agriculture: A life cycle assessment perspective. Landscape and Urban Planning 111: 68-78.

Lang, T., and D. Barling. 2012. Food security and food sustainability: Reformulating the debate. The Geographical Journal 178(4): 313-326.

Le Grand, L., and M. van Meekeren. 2008. Urban-rural relations: Dutch experiences of the LEADER+ network and rural innovation in areas under strong urban influences. In Rurality near the city-Proceedings of the international conference and workshops held in Leuven, Belgium, on February 7-8th, 2008, ed. V. Dewaelheyns and H. Gulinck, 95-100. Leuven.

Levy, K. 2008. Sustainability in Philadelphia: Community gardens and their role in stormwater management. Philadelphia: The Mill Creek Farm. http://www.chrishillmedia.com/millcreekfarm/ Levy_Kevin.pdf. Accessed 9 Sept 2011.

Locascio, S.J. 2005. Management of irrigation for vegetables: Past, present, and future. HortTechnology 15(3): 482-485.

Lockeretz, W., J. Freedgood, and K. Coon. 1987. Farmers' views of the prospects for agriculture in a metropolitan area. Agricultural Systems 23(1): 43-61.

Lohrberg, F. 2001. Stadtnahe Landwirtschaft in der Stadt- und Freiraumplanung. In Wechselwirkungen, 17-25.

Lovell, S.T. 2010. Multifunctional urban agriculture for sustainable land use planning in the United States. Sustainability 2(8): 2499-2522.

Macias, T. 2008. Working toward a just, equitable, and local food system: The social impact of community-based agriculture. Social Science Quarterly 89(5): 1086-1101.

Martin, G., R. Clift, I. Christie, and A. Druckman. 2014. The sustainability contributions of urban agriculture: Exploring a community garden and a community farm. In Proceedings of the 9th international conference on life cycle assessment in the agrifood sector (LCA Food 2014), ed. R. Schenck, and D. Huizenga, 
752-760. San Francisco, CA: American Center for Life Cycle Assessment.

Masson-Minock, M., and D. Stockmann. 2010. Creating a legal framework for urban agriculture: Lessons from Flint, Michigan. Journal of Agriculture, Food Systems and Community Development 1(2): 41-58.

Mbiba, B. 2003. Financing city farms in London. Urban Agriculture Magazine 9: 20-22.

McClintock, N., E. Pallana, and H. Wooten. 2014. Urban livestock ownership, management, and regulation in the United States: An exploratory survey and research agenda. Land Use Policy 38: 426-440.

Meenar, M., and B. Hoover. 2012. Community food security via urban agriculture: Understanding people, place, economy, and accessibility from a food justice perspective. Journal of Agriculture, Food Systems, and Community Development 3(1): 143-160.

Mees, C. 2007. Urban gardens and poverty: An analysis on the example of the community gardens in the South Bronx of New York City. Acta Horticulturae 762: 205-220.

Mees, C. 2010. A public garden per resident? The socio-economic context of homes and gardens in the inner city. Acta Horticulturae 881: 1057-1062.

Mees, C., and E. Stone. 2012. Food, homes and gardens: Public community gardens potential for contributing to a more sustainable city. In Sustainable food planning, ed. A. Viljoen, and J.S.C. Wiskerke, 431-452. Wageningen: Wageningen Academic Publishers.

Mendes, W., K. Balmer, T. Kaethler, and A. Rhoads. 2008. Using land inventories to plan for urban agriculture: Experiences from Portland and Vancouver. Journal of the American Planning Association 74(4): 435-449.

Metcalf, S.S., and M.J. Widener. 2011. Growing Buffalo's capacity for local food: A systems framework for sustainable agriculture. Applied Geography 31(4): 1242-1251.

Mok, H.-F., V.G. Williamson, J.R. Grove, K. Burry, S.F. Barker, and A.J. Hamilton. 2014. Strawberry fields forever? Urban agriculture in developed countries: A review. Agronomy for Sustainable Development 34(1): 21-43.

Mougeot, L.J.A. 2001. Urban agriculture: Definition, presence, potentials and risks. In Growing cities, growing food: Urban agriculture on the policy agenda, ed. N. Bakker, M. Dubbeling, S. Gündel, U. Sabel-Koschella, and H. De Zeeuw, 1-42. Feldafing: DSE/Zentralstelle für Ernährung und Landwirtschaft.

Mrohs, E. 1979. Peri-urban agriculture in the Rhein-Ruhr region (Duisburg-Dortmund, Bonn and Cologne). In Agriculture in the planning and management of peri-urban areas. Volume II. Case studies presented by OECD member countries and reports on selected policy issues, ed. OECD, II:165-212. Paris: OECD.

Müller, C. (ed.). 2011. Urban Gardening: über die Rückkehr der Gärten in die Stadt. München: Oekom.

Munton, R. 2009. Rural land ownership in the United Kingdom: Changing patterns and future possibilities for land use. Land Use Policy 26: S54-S61.

Murray, H., T.A. Pinchin, and S.M. Macfie. 2011. Compost application affects metal uptake in plants grown in urban garden soils and potential human health risk. Journal of Soils and Sediments 11(5): 815-829.

Nelkin, J., and T. Caplow. 2007. Floating hydroponics in the big apple. The Growing Edge 18(4): 38-40.

Nolasco, J. 2011. Sustainable water management for urban agriculture: Planting Justice. Oakland, CA: Working Paper Pacific Institute.

Grün, Nomadisch (ed.). 2012. Prinzessinnengärten. Anders gärtnern in der Stadt. Köln: Dumont.
Oenema, O. 2004. Governmental policies and measures regulating nitrogen and phosphorus from animal manure in European agriculture. Journal of Animal Science 82: E196-E206.

Orsini, S. 2013. Landscape polarisation, hobby farmers and a valuable hill in Tuscany: Understanding landscape dynamics in a periurban context. Geografisk Tidsskrift-Danish Journal of Geography 113(1): 53-64.

Patel, I.C. 1996. Rutgers urban gardening: A case study in urban agriculture. Journal of Agricultural and Food Information 3(3): $35-46$.

Paül, V., and F.H. McKenzie. 2013. Peri-urban farmland conservation and development of alternative food networks: Insights from a case-study area in metropolitan Barcelona (Catalonia, Spain). Land Use Policy 30(1): 94-105.

Pearson, L.J., L. Pearson, and C.J. Pearson. 2010. Sustainable urban agriculture: Stocktake and opportunities. International Journal of Agricultural Sustainability 8(1/2): 7-19.

Péron, J.Y., and E. Geoffriau. 2007. Characteristics and sustainable development of peri-urban vegetable production in Europe. Acta Horticulturae 762: 159-170.

Piorr, A., J. Ravetz, and I. Tosics (eds.). 2011. Peri-urbanisation in Europe: Towards European policies to sustain urban-rural futures. Copenhagen: University of Copenhagen, Forest and Landscape.

Pothukuchi, K. 2004. Community food assessment: A first step in planning for community food security. Journal of Planning Education and Research 23: 356-377.

Pothukuchi, K., and J.L. Kaufman. 1999. Placing the food system on the urban agenda: The role of municipal institutions in food systems planning. Agriculture and Human Values 16(2): 213-224.

Prain, G., and H. De Zeeuw. 2007. Enhancing technical, organisational and institutional innovation in urban agriculture. Urban Agriculture Magazine 19: 9-15.

Primdahl, J., and LSøderkvist Kristensen. 2011. The farmer as a landscape manager: Management roles and change patterns in a Danish region. Geografisk Tidsskrift-Danish Journal of Geography 111(2): 107-116.

Rodriguez, O. 2009. London rooftop agriculture: A preliminary estimate of productive potential. Master Thesis. Cardiff: Welsh School of Architecture.

Rosol, M. 2010. Public participation in post-fordist urban green space governance: The case of community gardens in Berlin. International Journal of Urban and Regional Research 34: 548-563.

Rosol, M. 2011. Subproject 1: Community gardens in Berlin: A new form of citizen participation. In Perspectives in urban ecology: Studies of ecosystems and interactions between humans and nature in the metropolis of Berlin, ed. W. Endlicher, 263-270. Dordrech: Springer.

Saldivar-Tanaka, L., and M.E. Krasny. 2004. Culturing community development, neighborhood open space, and civic agriculture: The case of Latino community gardens in New York City. Agriculture and Human Values 21: 399-412.

Säumel, I., I. Kotsyuk, M. Hölscher, C. Lenkereit, F. Weber, and I. Kowarik. 2012. How healthy is urban horticulture in high traffic areas? Trace metal concentrations in vegetable crops from plantings within inner city neighbourhoods in Berlin, Germany. Environmental Pollution 165: 124-132.

Schmelzkopf, K. 1995. Urban community gardens as contested space. Geographical Review 85(3): 364-381.

Schmelzkopf, K. 2002. Incommensurability, land use, and the right to space: Community gardens in New York. Urban Geography 23(4): 323-343.

Schmierer, M., F. Asch, and J. Sauerborn. 2010. Aeroponics as potential system for fully controlled staple food production. Abstract. In Tropentag 2010, book of abstracts. World food 
system-A contribution from Europe. ed. W. Tielke, 339. Witzenhausen: DITSL GmbH.

Scialabba, N., and C. Hattam (eds.). 2002. Organic agriculture, environment, and food security. Environment and natural resources series no. 4. Rome: FAO.

Segal, A. 2010. Food deserts: A global crisis in New York City causes, impacts and solutions. The Journal of Sustainable Development 3(1): 197-214.

Smith, V.M., R.B. Greene, and J. Silbernagel. 2013. The social and spatial dynamics of community food production: A landscape approach to policy and program development. Landscape Ecology 28(7): 1415-1426.

Smit, J., and J. Nasr. 1992. Urban agriculture for sustainable cities: Using wastes and idle land and water bodies as resources. Environment and Urbanization 4: 141-152.

Specht, K., R. Siebert, I. Hartmann, U.B. Freisinger, M. Sawicka, A. Werner, S. Thomaier, D. Henckel, H. Walk, and A. Dierich. 2014. Urban agriculture of the future: An overview of sustainability aspects of food production in and on buildings. Agriculture and Human Values 31(1): 33-51.

Spliethoff, H.M., R.G. Mitchell, L.N. Ribaudo, O. Taylor, H.A. Shayler, V. Greene, and D. Oglesby. 2014. Lead in New York City community garden chicken eggs: Influential factors and health implications. Environmental Geochemistry and Health 36(4): 633-649.

Steel, C. 2009. Hungry city: How food shapes our lives. London: Vintage Books.

Sullivan, W.C., O.M. Anderson, and S.T. Lovell. 2004. Agricultural buffers at the rural-urban fringe: An examination of approval by farmers, residents, and academics in the Midwestern United States. Landscape and Urban Planning 69(2/3): 299-313.

Swaffield, S., and J. Primdahl. 2006. Spatial concepts in landscape analysis and policy: Some implications of globalisation. Landscape Ecology 21(3): 315-331.

Thibert, J. 2012. Making local planning work for urban agriculture in the North American context: A view from the ground. Journal of Planning Education and Research 32(3): 349-357.

Travaline, K., and C. Hunold. 2010. Urban agriculture and ecological citizenship in Philadelphia. Local Environment 15: 581-590.

Trienekens, J., and P. Zuurbier. 2008. Quality and safety standards in the food industry, developments and challenges. International Journal of Production Economics 113(1): 107-122.

Turner, B. 2011. Embodied connections: Sustainability, food systems and community gardens. Local Environment 16(6): 509-522.

United Nations. 2012. World urbanization prospects-The 2011 revision. Final Report. New York: United Nations, Department of Economic and Social Affairs, Population Division.

Van den Berg, A.E., M. van Winsum-Westra, S. de Vries, and S.M.E. van Dillen. 2010. Allotment gardening and health: A comparative survey among allotment gardeners and their neighbors without an allotment. Environmental Health 9(1): 74.

Van der Schans, J.W., and J.S.C. Wiskerke. 2012. Urban agriculture in developed economies. In Sustainable food planning, ed.
A. Viljoen, and J.S.C. Wiskerke, 245-258. Wageningen: Wageningen Academic Publishers.

Vidal, R., and A. Fleury. 2008. Agriculture in urban planning in Îlede-France. In Rurality near the city-Proceedings of the international conference and workshops held in Leuven, Belgium, on February 7-8th, 2008, ed. V. Dewaelheyns, and H. Gulinck, 75-82. Leuven: KU Leuven.

Vogl, C.R., P. Axmann, and B. Vogl-Lukasser. 2004. Urban organic farming in Austria with the concept of Selbsternte ('selfharvest'): An agronomic and socio-economic analysis. Renewable Agriculture and Food Systems 19: 67-79.

Voicu, I., and V. Been. 2008. The effect of community gardens on neighboring property values. Real Estate Economics 36(2): 241-283.

Wittwer, S.H., and N. Castilla. 1995. Protected cultivation of horticultural crops worldwide. HortTechnology 5(1): 6-23.

Zasada, I. 2011. Multifunctional peri-urban agriculture-A review of societal demands and the provision of goods and services by farming. Land Use Policy 28: 639-648.

Zasada, I. 2012. Peri-urban adaptation strategies of horticultural farms in the Berlin metropolitan area. Cahiers Thématiques Architecture et Paysage Conception/Territoire/Histoire Agriculture Métropolitaine/Métropole agricole: 131-140.

Zasada, I., R. Berges, J. Hilgendorf, and A. Piorr. 2013. Horsekeeping and the peri-urban development in the Berlin metropolitan region. Journal of Land Use Science 8(2): 199-214.

Zasada, I., C. Fertner, A. Piorr, and T.S. Nielsen. 2011. Periurbanisation and multifunctional adaptation of agriculture around Copenhagen. Geografisk Tidsskrift 111(1): 59-72.

Ina Opitz studied Geography at the Humboldt University of Berlin. She worked on the topic of urban agriculture, zfarming and innovation in research projects at the Leibniz Centre for Agricultural Landscape Research (ZALF), Institute of Land use systems.

Regine Berges studied Geoecology at the University of Potsdam. She works at ZALF, Institute of Socio-Economics, on the topics of periurban and urban agriculture and their environmental impacts.

Annette Piorr studied and took her doctoral degree in Agricultural Sciences at the University of Bonn. She is head of a research group at the Institute of Socio-Economics at the ZALF and coordinator in several EU and state funded research projects dealing with peri-urban and urban agriculture, rural develpoment policies and the food system in general.

Thomas Krikser studied political science at the Freie Universität Berlin. He is PhD candidate at the Leuphana University Lüneburg and currently lecturing empirical social research at the University of Kassel. At ZALF he focused on qualitative research methods and sociology. 